\title{
戦後東北地方における生活改善普及事業
}

一農林省の基本方針に対する青森県の対応一

\author{
中間由紀子 1$) *$ ・内田 和義 1$)$
}

\section{Extension Services for Home Living Improvement in Post-war Tohoku: Aomori Prefecture's Response to the Ministry of Agriculture and Forestry's Basic Policy}

\author{
Yukiko Nakama1)* \& Kazuyoshi Uchida ${ }^{1)}$
}

For the Ministry of Agriculture and Forestry (MAF), the aims of the extension services for home living improvement included improving living conditions of farmers and spreading democracy in rural villages. It adopted a policy of cultivating home living improvement groups on the model of women's common-interest associations as the organizational agents of the service. This study discusses how local authorities in the Tohoku region responded to the basic policies of the MAF's extension services for home living improvement, with a focus on Aomori prefecture. The study demonstrates that, although Aomori attempted to accept the MAF's basic policy, it was initially forced to implement the improvements through existing men's organizations - an unavoidable response given the social realities of the farming villages. As improvement activities began in earnest, however, women gradually took over as their primary movers.

キーワード : 戦後農政, 生活改善普及事業, 生活改善グループ, 生活改善指定部落

1. はじめに

戦後改革期に打ける主要な農業政策の一つに，協 同農業普及事業（以下，普及事業）がある. 戦後ア メリカから導入され，1948 年に開始された普及事業 は，農業改良普及事業，生活改善普及事業，青少年 教育の 3 つで構成される.

本稿が対象とする生活改善普及事業（以下，生改 事業）は，農村女性を主たる対象として実施された 事業である。生改事業については, 生活経営学（天 野, 1995), 歴史学（大門，2003）, 民俗学（安井, 2006）など様々な分野からアプローチがなされてい る. しかしその多くは，事業の担い手である生活改 善グループ（以下，生改グループ）扎よびその指導 に当たった生活改良普及員（以下，生改普及員）の
活動事例に関する研究である. これに対して市田知 子は, 生改事業の主管である農林省生活改善課の「生 活改善の理念」について検討している（市田, 1995).

筆者は市田の研究に学びながら，新たな資料を用 いて農林省の生改事業に対する基本方針を検討し た。さらに，農林省の方針に対し，自治体がぞのよ らに対応したのかについて中国地方の 3 県（鳥取, 島根，山口）を事例に考察した。農林省の生改事業 の目的は，農家生活の改善とともに農村を民主化す ることにあった（農林省，1972：p. 1076）。そのた めの受入組織として，女性による同志的な生改グル ープの育成を行らことを方針とした。 上意下達的な 性格を持つ婦人会を利用してはならないとした（農 林省， 1948 : pp. 15-16). 鳥取県は，農林省の方針

\footnotetext{
1) 島根大学生物資源科学部; Faculty of Life and Environmental Science, Shimane University

* E-mail: nakama@life.shimane-u.ac.jp 
に忠実に従い，自主的なグループの育成を行った。 しかし，当時は女性が自主的にグループを作るのは 難しく, 結果的に婦人会が事業を担う形になった（中 間他，2008). 島根県は農家生活の改善を優先課題 とした。効率性を重視し，婦人会を通してグループ 育成を行った（中間他，2009）。山口県は公式には 自主的なグループの育成を掲げたが，実際には婦人 会を利用した（中間他，2010）。自治体によって対 応が異なった要因は, 農林省との人的交流の深浅, 事業担当者の出自等にあったことを明らかにした.

本稿では, 中国地方とは異なる農村社会を有して いた東北地方を対象に，農林省の基本方針に対する 自治体の対応について考察する.ささに，そらした 対応をとった要因についても追究する. 東北地方の 自治体を考察の対象として取り上げるのは，生改事 業を導入・遂行するに当たり, 農村社会の性格が事 業に何らかの影響を与えたのではないかと考えるた めである. 本稿では, 東北地方のなかでも「他県に 比し封建的慣習の残存が甚し」（青森県, 1952 : p. 2)いとされた青森県を事例に考察を行う.

\section{2. 青森県における生活改善普及事業の方針 (1) 農業改良課の設置}

1948 年 8 月の「農業改良助長法」の施行により, 普及事業が発足する。同月 6 日，農林省内に担当部 局として農業改良局が設置される。同月 20 日には, 農林次官から各都道府県知事宛に「新農業普及制度 確立促進の件」に関する通牌が出される。通牒の主 旨は，主務課の新設にあった。既設の農務課ではな く，新たに普及事業の専任課を設置して業務に当た るべきだとしたのである，当時，農務課の主要な業 務は食糧の供出にあった。 普及事業担当の職員は, こうした行政事務に関与してはならず，あくまでも 普及事業に専念すべきであるとされた，そのために， 主務課の新設が強く要請されたのである. 課の名称 は，「農林省に新設された農業改良局の名称」に応じ て「農業改良課」とすることが適当だとされた（農 林省, $1949:$ p. 4).

青森県は, 1948 年 11 月 1 日, 経済部内に普及事 業の主務課を新設する。名称は農林省の指示に従い 「農業改良課」とした（青森県，1958：p. 5）‥農業 改良課の設置と同時に，青森県に扣いて普及事業が
開始される.

\section{（2）生活改善普及事業の方針}

生改事業は戦後日本に導入された新しい事業であ り，受入側の農村の人々にとっては，全く馴染みの ないものであった，そこで青森県は，生改事業とく に指導に当たる生改普及員の存在について周知を図 るため，1948 年に資料を発行している. 文中には, 生改普及員の役割は「農村生活」を「向上」させる ことにあると述べられている. その方法は，上から の指導ではなくあくまでも「婦人のみなさんととも に考え」ることであるとされている（青森県, 1958 : p. 3).

上述したように青森県の生改事業の主要な目的 は,「農村生活」の「向上」にあったが, もら一つの 重要な目的が農村の民主化，自主的な農民の育成で あった，農業改良課長の村越信夫は，「若い改良普及 員」に向けて次のよらに述べている（村越, 1950 : p. 3).

この改良普及事業が始つてから，恰度一ヶ年に なつたばかりであるから，まだ農民の頭を民主的 思想にきりかへて自主的に働きだせるようにする までには，時間がかかると思ふ（中略）改良普及 員は農家の農業技術への案内役であり，時には先 生であり，又時には同僚でもあるから，先づ何よ り第一に農業や農村生活に深い理解をもち農民に 信頼され親しまれる人柄をもたねばならぬ. 同時 に農業経営について充分理解し親心をもつて農家 の相談相手になる心持が大切である.

村越は，自主的な農民，当時よく使われた言葉で いえば「考觉る農民」2の育成を重視していた。た だし，その実現には時間がかかるといらことを認識 した上で指導に当たらなければならないとしている. さらに，普及員はあくまでも「農家の相談相手」で なければならないとも述べている，村越が従来の上 からの指導ではなく，農民の自主性を重視する普及 事業について理解していたことがわかる.このよら に，普及事業の主要な目的は，自主的な農民の育成 ひいては農村の民主化にあったのである，農村の民 主化，「考光る農民」の育成といら考光は，現場の普 及員にも徐々に浸透していく3.

青森県は, 1950 年に「生活改善指定部落」（以下, 指定部落）制度を導入する. 制度の目的は，「重点的 
な指導によつて生活の合理化を図り，そして生活文 化の育成向上に努めて，模範的なモデル部落」を育 成し，「以て他部落の水準となす」ことにあった（坂 本，1950：p. 24). 指定部落として選定されたのは, 東津軽郡小湊町盛田, 南津軽郡石川町森山, 北津軽 郡松島村悪戸，上北郡浦野舘村大浦，三戸郡猿辺村 葛子平の 5 つである（坂本，1951a：pp. 32-36，坂 本, 1951b : pp. 28-30). 津軽地域から $3 つ$, 南部地 域から $2 つ の$ 集落が選ばれている。「選定の基準」 は，「部落民の人的和のよくとれたところであつて， 協力的且つ積極性のあるところで，乙かも改善の意 欲の旺盛なところ」とされた（坂本，1950：p.24）. 指定された部落には，活発に活動する農事研究会な ぞの男性の組織があり, 生改事業の受入組織とな った。

青森県は, 農家生活の改善, 農村の民主化といら 農林省の生改事業の目的を受け入れる。しかし，女 性ではなく既存の男性組織を受入組織とする指定部 落制度を導入したのである.

\section{（3）対応の要因}

青森県は，農林省の基本方針を受け入れょらとし た．とくに，農村の民主化といら考光を受け入れた 要因として第一にあげられるのは，農業改良課長・ 村越信夫の存在である。村越は, 1896 年に神奈川県 に生まれ，1921 年に北海道帝国大学を卒業する（満 蒙資料協会，1941：p. 155)。卒業後すぐに満州に渡 り（村越, 1965 : p. 319), 農事試験場に勤務する. 在職中, ウィスコンシン大学に留学し，1930 年に同 大学を卒業している (Berge, 1939 : p. 370). 注目 すべきは，村越が普及事業の発祥の地であるアメリ カの大学を卒業しているといら点である．留学によ り，民主主義に直に触孔，そ礼詨寸る理解を深め たのではないかと考光られるからである。また，ア メリカの普及事業は, 州立大学を中心とするところ に特徴がある. 村越が留学したウィスコンシン大学 ももちろん普及事業に深く関与していた（Mclntyre, 1962)。村越は同大学で学ぶ過程で普及事業に触れ る機会があったと推測される。そのため，戦後日本 に導入された際も違和感なく受け入れることができ たのである，アメリカ流の民主主義と普及事業に深 い理解のある村越の存在は，青森県の事業方針に強 い影響を与えたと考えられる。
$2 つ$ 目の要因は，軍政部とのつながりである．終 戦後, 地方自治体は, アメリカ陸軍の下部組織であ る軍政部の管理下に置かれる。その役割は，地方自 治体に打いて GHQ の施策がぞのように実施されて いるかを監視することにあった（竹前, 1983 ：p. 56)。軍政部之の折衝は, 英語が堪能な村越が当たっ た. 担当官の多くは， ウィスコンシン大学の卒業生 であり, 村越の後輩であった（林，1958：p.9）。そ のことが青森県と軍政部との結びつきを強めた可能 性がある ${ }^{4}$. 担当官は, 同空の村越を通じて普及事 業の方針を徹底させようと試及，村越もそ饥応じ たのではないかと推測される.

一方で，指定部落制度を導入したのはなぜであっ たのだろらか，第一の要因として，当時の農村の実 情があげられる．青森県は「本州の最北端」にある 関係上，農業生産の条件不利地域であった。農家は 貧しく,「凶作」,「青田売」,「身売」に象徵される 「東北農業の宿命的な惨めさ」を生み出すことにもな った，農業に打ける「自然的，経済的後進性」は， 農村社会の性格にも影響を与えた。「農村の多くは民 主的構成とははるかに遠い社会環境」下に置かれて いた（青森県，1952：p.2）。このような状況におい て，家や社会の中で低い地位を強いられていた女性 が初めから事業の主体になるのは非常に困難であっ た。 ましてや，女性を成員とする組織の育成は不可 能であった。そ它のめに，やむなく既存の男性組織 に頼らざるを得なかったのである.

第 2 の要因は生改普及員の不足である。青森県に 生改普及員が配置されたのは 1949 年である。当時 の指導地区 30 飞対し, 生改普及員数は 5 名であっ た（青森県，1958：pp. 15-17）。当時の普及体制で は「到底県下全般に亘つて, 生活改善の普及効果を 収めること」は困難であった（坂本，1950：p.24）. 指定部落を選定し，集中的に指導を行い，そこから 周囲に波及させることが生改事業を県下に広める最 も効率的な方法であったといえる。

第 3 の要因は, 1949 年 6 月 $15 ， 16$ 日に岩手県で 開催された「農業普及事業東北北海道ブロック会議」 である、会議には各県の主務課長等が出席し，普及 事業に関するさまざまな議論が行われた，生改普及 員関する議論では,「啓蒙宣伝して存在を認めさせ ると共にモデル村を作るなど活動促進する外養成講 
習会を開きたい」といら結論が出された（宮城県, 1949a : p. 3). この中で注目すべきは「モデル村を作 る」といら箇所である.「模範的なモデル」となる地 域を育成するといら点で指定部落制度の内容と一致 している。 また，会議の出席者である宮城県は，同 月 6 日の時点で県内に「生活改善指導部落」を設置 することを決定していた（宮城県，1949b : pp. 2-3). 議場で同県の現状について触れたことは想像に難く ない，指定部落制度の導入は，ブロック会議の議論 扣よび宮城県の先例を参考にして実施された可能性 がある 5 .

青森県は，農林省の基本方針を受け入れよらと試 みた。しかし，実行段階に扣いては農村の実情执よ び現行の普及体制を考慮し，やむを得ず現実的な対 応をとったのである。

\section{3. 青森県における生活改善普及事業一生活改善 指定部落の事例一}

1950 年, 青森県は「模範的なモデル部落」を育成 すべく，盛田，森山，悪戸，大浦，葛子平の 5 集落 を指定部落として選定する，指定部落では，生改普 及員扣よび農業改良普及員（以下，農改普及員）の 協力の下，生活改善が実践される。本稿では，一例 として三戸郡猿辺村葛子平を取り上げる.

葛子平は，旧国鉄三戸駅から徒歩 2 時間といら「五 つの指導部落のらちで, 地域的にも一番不便なとこ ろ」(坂本, 1951b : p. 29) にある「戸数二十一戸」 の「山間僻地と云らにふさわしい一小部落」であっ た（高木，1952：p.4）。「昔から農業経営から見て も生活の面から見ても最低以下の生活」を送らざる を得ない状況下にあった，それに追い打ちをかけた のが，1947 年 4 月に発生した火災である. この火災 によって「十七戸が一物もなく焼失」し，人々の暮 らしはますます苦しくなっていった，当時，満州か ら復員したばかりであった佐々木政吉 ${ }^{6}$ は,「此のま っでは駄目だ，なんとかしなければならない」と考 え，集落の同年代の青年らと話し合いを行ら。この 話し合いにより，「農業経営の合理化と生活の様式の 改善を図るのが先決問題であるといらことに意見が 一致」する．佐々木らの意見に賛同した十数名の同 志により，1948 年 4 月，「農業研究会」が結成され る (高木, 1952 : p. 4).
同年 11 月，青森県に执いて普及事業が開始され， 三戸地区にも農改普及員 3 名, 生改普及員 1 名の計 4 名が駐在するよらになる。赴任挨拶をか水て初め て葛子平に足を踏み入れた普及員らは，「なる程ひど い処だと感じ，普及事業の手始めにこの部落から手 をつけよう，そして少くとも経営，生活の両面を三 戸平坦地方の農家の水準までに引上げよう」と考光 る（田中, 1953 : p. 22). 1949 年 5 月頃, 猿辺村の 下田小学校に於いて，生活改善専門技術員の坂本静 枝を講師に「生活改善講演会」が開かれる. 坂本の 話を聞いた佐々木らは,「農業経済の立直しは農業経 営の改善と共に生活の改善も併せてやらなければそ の効がないことを自覚」する．講演会を契機に，生 活改善に関する知識を得るため, 度々普及所に赴く ようになる.三戸地区の主任であった田中治五郎は, 佐々木らの熱意に着目し，「その様に一生懸命やる意 欲があるなら今県では生活改善の指定部落をつくる んだがやつたらどらか」と話をもらかける。生活改 善に対して強い意欲を持っていた佐々木らは，喜ん で指定部落の話を受ける，葛子平は，三戸地区普及 所の強い後押しを受け，県から指定部落として選定 されるのである（高木, $1952:$ p. 4).

選定後，最初に行った活動は「月一回の布団干の 励行」と「万年床の廃止」であった. 経済的に貧し い葛子平では，生活改善に金をかける余裕は無かっ た. そのためにまず「金の掛らぬことで最もやりや すいこと」から着手したのである. 布団干は心掛け 一つで誰にでも出来るといらことから，「皆喜んで実 行」した，次に実施したのが「共同吸上げポンプ井 戸」の設置である．葛子平の汇とんどの家は川の水 を飲料水として利用して扣り，「不衛生極まりない状 態」であった。 また，川から水を汲むのは女性の仕 事であり，その負担は非常に大きかった。衛生面抒 よび女性の労働面から, 飲料水の改善は集落の喫緊 の課題であった. この状況を改善すべく，県の助成 を得て，集落の 11 ヶ所に「共同吸上ポンプ井戸」を 設置する．井戸が出来たことにより，集落の人々は 綺麗な水が使用できるようになる，水源が近くなっ たため, 水汲夕の負担が軽減され, 「労力的にも又精 神的にも非常に楽になつたと主婦達から喜ばれ」た。 さらに，集落に 2 戸しか無かった風呂が 10 戸の家 に新設された（高木，1952：p.8）。一連の活動の成 
功を機に,「食生活の向上」,「住生活と衛生の改善」, 「くらしの共同化」など様々な活動が行われていく (坂本，1952：pp. 22-24）。なかでも特筆すべきは, 女性による「生活改善の研究会」の結成である，葛 子平には, 「田植兄終了後四五日休み, その外に草刈 休久，花見休及，正月休及，打盆休及と年を通して は一ケ月位たぶ食べて遊」ぶ「テンノリ」といら習 慣があった。しかし，貴重な休みを無䭾にせず，有 効活用すべきではないかと集落の人々は考光るょう になる。 そこで「此の休みを振向けて」, 男性は毎月 1 日に「農事研究会」の例会を，女性は 15 日に「生 活改善の研究会」の例会を開くことに決める（高木, 1952 : pp. 8-9). 葛子平の生活改善の担い手は, 佐 々木ら男性から女性へと移っていくのである。

\section{4. おわりに}

青森県は，農林省の生改事業の基本方針を受け入 机ようと試みた，事業の目的は，農村生活の「向上」 と自主的な農民の育成とした。 ただし，事業の遂行 に当たっては，既存の男性組織を受入組織とする指 定部落制度を取り入れた。

青森県が生改事業の目的，とくに「農村の民主化」 を受け入れた第一の要因は, 農業改良課長の村越信 夫の存在にあった，村越はウィスコンシン大学に留 学経験があり，アメリカの民主主義拈よび普及事業 について深く理解していた，そのため戦後，日本に 普及事業が導入された際，事業目的や内容を違和感 なく受け入れることができたのである．村越の存在 は, 生改事業の方針飞影響を与える. 第二の要因は, 軍政部とのつながりである. 東北軍政部の担当官は, ウィスコンシン大学の卒業生で村越の後輩であった. そのことが農業改良課と軍政部との結びつきを強め, 事業の方針に反映されたのである。

青森県は，農林省の基本方針を受け入れつつ，指 定部落制度を導入した。 その要因は, 農村の実情, 生改普及員の不足, 東北北海道ブロック会議への参 加にあった。なかでも一番重要な要因が農村の実情 である。これまで筆者が考察してきた中国地方の 3 県では，自主的な女性グループの結成こそ困難であ ったが，婦人会等の女性組織が事業の受入組織とな った，しかし，青森県では，農村社会の閉鎖的な性 格から自主的な組織をつくることは抢ろか，女性だ
けで活動を行らことすら難しい状況にあった。そこ で既に農事研究会などの男性組織が活発に活動して いた地域を指定部落として選定し，それらを事業の 受入組織とした，女性組織の育成は断念したのであ る。ただし，指定部落の多くは，本稿で取り上げた 葛子平のように，生活改善を本当に必要としていた 地域が選ばれている7 . 生活改善の内容に関しては, 普及員が上から押しつけるのではなく, 集落側が本 当に必要としていた項目から着手している．農民の 自主性を重視する生改事業の精神が生かされていた といえよう。また，指定部落選定は，女性が表に出 る機会を与光た，葛子平では当初，男性が生活改善 の担い手であったが，活動が本格的になると女性が 「生活改善の研究」のための集まりを持つょうにな る。新たに女性組織が結成される場合もあった，上 北郡の大浦集落は，「婦人の組織がなく，婦人の活動 は全く見られなかつた」が，指定を機に「婦人会」 が集落内に新たに結成されている（坂本，1951b：p. 28)。「婦人会」は農村の全戸を対象とする網羅的な 組織であり，自主的な組織ではない。しかし，女性 だけの組織が存在しなかった地域に新たに女性組織 がっくられたということは，非常に画期的であった といえよう。

指定部落の設置は農村の実情に応じてやむなく取 られた方法であった．しかしそれは，本来生改事業 を担うべきとされた女性を表舞台に引き出すという 意味で重要な役割を果たしたといえる，指定部落の 活動は，周辺地域にぞのような影響を与えたのであ ろらか。青森県に抢沙る生改事業の詳細を明らかに するためには，この点について考察する必要がある.

\section{注}

1 隣県の岩手県は, 農林省の指示に抗して「農業改良課」を設 置せず，既設の「農務課」が事業を担当した（岩手県, 1949).

2「考光る農民」は，農林省農業改良局長（2代目）であった小 倉武一が提唱した言葉である（小倉, 1981 : p. 331).

3 農業改良普及員の大谷慶作は「普及事業に特に魅力を感じ た」のは，「考える農民」を育てるといら農民教育の理念を 実践しらること」にあったと述べている (大谷, 1978: p. 10).

4 青森県の普及機関誌である『青森農業』の創刊号の巻頭言 は，東北民事部（旧東北軍政部）天然資源課のカール・エ フ・デリカが執筆している（デリカ，1950：pp. 1-2）.

5 隣県の岩手県も 1950 年に「生活改善指定部落」制度を導入 し, 県下に 5 つの指定部落を設置している(瀬川, 1950 : p. 5). 
6 佐々木晃氏，宇津沢義美氏からの聞き取り（2013 年 9 月 17 日，三戸郡三戸町葛子平)。

7 例えば東津軽郡の盛田集落は, 赤痢や腸チフス等の伝染病患 者が多く, 衛生面の改善が急務であった (坂本, 1951a:p. 33).

\section{引用文献}

青森県経済部農務課（1958）『農業改良普及事業十周年記念』. 青森県農地改革史編篡委員会編（1952）『青森県農地改革史』 農地委員会青森県協議会.

天野寛子（1995）「戦後の農家の生活改善について」『昭和女子 大学女性文化研究所紀要』15,47-66.

市田知子（1995）「生活改善普及事業の理念と展開」『農業総合 研究』49(2), 1-63.

岩手県農務課（1949）「昭和二十四年度 協同農業普及事業の 概要」.

大門正克（2003）「生活を改善するといらこと」『山梨県史研 究』11, 79-104.

大谷慶作（1978）「普及活動の思い出」五所川原地区農業改良 普及所編『普及事業 30 年のあゆみ』五所川原地区農業改 良普及事業協議会, 9-10.

小倉武一（1981）『小倉武一著作集第 5 巻』, 農山漁村文化協会. カール・エフ・デリカ（1950）「農業改良普及事業の重要性」 『青森農業』1, 1-2.

坂本静枝（1950）「生活改善指定部落の模様（一)」『青森農業』 $1(5), \quad 24-26$

坂本静枝（1951a）「生活改善指定部落の一年を顧みる (一)」 『青森農業』2(7), 32-36.

坂本静枝（1951b）「生活改善指定部落の一年を顧みる（完）」 『青森農業』2(8), 28-30.

坂本静枝（1952）「誕生二年の生活改善部落」『青森農業』3(8), $20-25$.

瀬川謙一（1950）「農村生活改善指定部落について」『農業普 及』 $2(8), 5$.

高木 緑（1952）「誌上座談会」『青森農業』3(5・6)，4-13.
竹前栄治（1983）『GHQ』岩波書店.

田中治五郎（1953）「葛子平部落のはなし」『県政のあゆみ』 $19,22-24$.

中間由紀子・内田和義・伊藤康宏 (2008)「生活改善実行グル ープと婦人会一鳥取県を事例に一」『農村生活研究』52(1), $12-21$.

中間由紀子・内田和義（2009）「戦後改革期に打ける生活改善 普及事業と婦人会一島根県を事例に一」『農林業問題研究」 45(1), 108-113.

中間由紀子・内田和義（2010）「生活改善普及事業の理念と実 態一山口県を事例に一」『農林業問題研究』46(1), 1-13.

農林省大臣官房総務課編（1972）『農林行政史』6.

農林省農業改良局普及部（1948）『第一回生活改善に関寸る懇 談会記録』.

農林省農業改良局普及部（1949）『普及だより』1.

林柾次郎（1958）「座談会“青森農業”の百号にあたつて (上)」 『青森農業』9(10), 5-10.

満蒙資料協会 (1941) 『満華職員録 康徳 9 年・民国 31 年版』. 宮城県農業改良課（1949a）「農業普及事業東北北海道ブロック 会議」『農業改良ニュース』7,3.

宮城県農業改良課（1949b）「農業改良事務所主任者会議」『農 業改良ニュース』7，2-3.

村越信夫（1950）「若い改良普及員のために」『青森農業』1，23.

村越信夫（1965）「満州の気象と適産物」『あ>満州』, 319-321. 安井眞奈美（2006）「村の暮らしを改善する」『山口県史研究』 $14, \quad 59-80$.

Berge, A.J. (ed.) (1939) The Wisconsin alumnus, Volume 40, Number 4. (http://digital.library.wisc.edu/1711.dl/UW.v40i4) [Accessed March 10, 2014]

Mclntyre, E.R. (1962) Fifty Years of Cooperative Extension in Wisconsin 1912-1962. Madison: Wisconsin Cooperative Extension Service. 